\title{
Precisamos conversar sobre os nossos 15 minutos
}

Júlio César Garcia de Alencar, MD PHD ${ }^{1}$

1 Faculdade de Medicina da Universidade de São Paulo (FMUSP), São Paulo/Brasil;

* Autor correspondente. Endereço de e-mail: julio.alencar@hc.fm.usp.br

"Medicina de Emergência são os 15 minutos mais interessantes de todas as outras especialidades (em tradução livre do inglês)". Confesso que essa frase sempre me causou inquietação. Não que ela esteja errada, ao contrário, mas ela está incompleta. Medicina de Emergência é muito mais do que isso, e nesse momento de construção de alicerces $e$ levantamento de paredes da especialidade no nosso país, precisamos falar sobre quais são os 15 minutos mais interessantes da Medicina de Emergência. E só dela.

Nas últimas três décadas, a especialidade tem se desenvolvido rapidamente tanto em países desenvolvidos, quanto em países em desenvolvimento, impulsionada pela melhoria dos sistemas de saúde, somada ao processo de urbanização de suas populações e a consequente transição epidemiológica de doenças infecciosas para doenças cardiorrespiratórias e decorrentes de trauma. Médicos Emergencistas se tornam cada vez mais necessários à medida que se somam uma porcentagem cada vez maior de pacientes idosos com necessidade de atendimento emergencial, catástrofes ambientais, guerras e ataques terroristas.

De fato, Medicina de Emergência tem sido praticada de maneiras diferentes em diferentes lugares, já que seu escopo de atuação depende de inúmeros fatores, incluindo o nível de desenvolvimento dos sistemas de saúde, os recursos disponíveis, a prevalência de doenças, a disponibilidade de médicos treinados e a demanda da população.

No Brasil, assistimos à expansão da especialidade, enquanto tentamos caminhar em direção a uma Sociedade 5.0, em que o foco do desenvolvimento de soluções tecnológicas é o bem estar humano, a qualidade de vida e a resolução de problemas sociais. E, meus amigos, sinto dizer, mas não vai dar para construir uma especialidade importando totalmente o conhecimento e o Mindset (palavra sem tradução livre) dos americanos ou de qualquer outro lugar que seja.

Precisamos também olhar para os nossos pacientes, atendidos nos nossos serviços de PréHospitalar e Departamentos de Emergência Hospitalares e, de forma objetiva, factível e ininterrupta, nos questionar como melhorar a nossa prática clínica. Precisamos fazer hipóteses direcionadas para essas oportunidades de melhoria, coletar dados, analisá-los, tirar conclusões e divulgálas, para que outros pacientes, médicos, equipes multiprofissionais e serviços de saúde também possam se beneficiar dessas pesquisas.

Sim, eu me entreguei: eu descrevi o Método Científico e estou aqui falando sobre Pesquisa em Medicina de Emergência. $E$, se esse tema também te dá inquietação, por favor, continue a leitura, porque a verdade é:

-Você pode se tornar um pesquisador!

Não por obrigação, titulação ou impulso, mas por propósito.

Quero deixar claro que é fundamental que façamos pesquisa em Medicina de Emergência, mas que está tudo bem se você, que me lê agora, não quiser ser pesquisador. Médicos brilhantes, professores inspiradores, gestores competentes, todos são bem-vindos nesse momento de construção. Meu objetivo aqui é tão somente te contar que é possível.

É bem verdade que os Departamentos de Emergência brasileiros, assim como os de todo o mundo, ainda são locais de pouca tradição em pesquisa. $O$ novo pesquisador desta especialidade certamente enfrentará dificuldades que o acompanharão desde a escolha do problema a ser resolvido até a publicação de seus resultados.

Lembro, por exemplo, que certa vez comentei com um pesquisador, um desses médicos super 
especialistas em alguma doença rara da unha do pé, sobre uma pergunta de pesquisa e as minhas hipóteses de como melhorar a assistência aos meus pacientes no Departamento de Emergência. Antes que eu pudesse pedir sua ajuda para desenharmos o estudo, ele sorriu de canto de boca e não segurou um: "Vocês da Emergência só conseguirão publicar artigos no Metrô News" (revista popular de circulação nos transportes públicos de São Paulo). Dia desses, recebi um e-mail do mesmo professor me parabenizando por uma publicação internacional. Confesso que poucas coisas na minha carreira de pesquisador foram tão gratificantes. Certamente, uma delas é fazer parte do Corpo Editorial do Jornal Brasileiro de Medicina de Emergência.

Desde que terminei o Doutorado e me tornei professor, recebo mensagens de Médicos Emergencistas perguntando por onde começar a fazer pesquisa, eu sempre respondo: comece lendo artigos científicos. Obviamente, não estou dizendo para você queimar seus livros, aposentar os blogs ou dar unfollow no \#MedTwitter. Estou pedindo para que você também beba da fonte. Aplicativos gratuitos como o Read $\AA$ e o Evidence Alert $\AA$ podem te ajudar a organizar o conteúdo publicado de acordo com as suas áreas de interesse e facilitam a separar o joio do trigo.

Pessoalmente, não acredito que existam fórmulas pré-prontas de como se fazer pesquisa. $\mathrm{Na}$ prática, ninguém sabe do que você precisa pesquisar mais do que você mesmo. Você conhece seus pacientes, seu hospital, seus colegas, seus recursos. Que perguntas não respondidas você tem sobre a Medicina de Emergência que pratica? Escolha uma pergunta e encontre a solução. Especialmente no início, sugiro que você também reflita sobre o quão ambicioso você é, e o quanto você acha que pode realizar com sucesso. Não adianta começar a pesquisar sozinho um projeto que precisaria de 10 pessoas e muitas habilidades técnicas para ser realizado. Lembrem-se: pequenos!

- Não há nada de errado com passos

Quanto mais pesquisa você faz, melhor você faz. Infelizmente, isso não acontece rápido. Mas, novamente, é uma das coisas mais gratificantes do mundo.

Quando os americanos discutiram sobre a aprovação da Medicina de Emergência enquanto especialidade, os principais críticos questionavam quais eram as competências, as áreas de atuação e o escopo de conhecimento pertencentes individualmente à Medicina de Emergência que a faziam uma especialidade médica. Cinquenta anos depois, lembro para todos vocês que Medicina de Emergência é muito mais do que os quinze minutos alheios. Curiosamente, a emblemática frase de Dan Sandberg foi cunhada na conferência Best Evidence in Emergency Medicine.

De ontem em diante, temos a honra de discutir a construção das paredes dessa especialidade, tão brilhantemente alicerçadas por pessoas inspiradoras do Nordeste ao Sul do país. É hora de nós também navegarmos em águas desconhecidas e certamente turbulentas, e começarmos a discutir gestão pública e privada, políticas educacionais e, sobretudo, pesquisa de qualidade em Medicina de Emergência.

E você, topa vir com a gente nesse BARCO? 